\title{
AT 75, NEW ASPIRATIONS FOR NEW DELHI?
}

\author{
Chintal Sharma \\ Architect, Shodh Design Workshop \\ https://dx.doi.org/10.12795/astragalo.2020.i27.04
}

"No capital in the world has been built on the site of as many legendary cities of old, as Delhi."

Patwant Singh, 1971

\section{INTRODUCTION}

The Central Public Works Department (CPWD), in early September 2019, issued a press notice inviting architects to compete for a redevelopment project of the Central Vista. The precinct which once symbolized British colonial power was appropriated post-Independence to celebrate the seat of the world's largest democracy. The area comprises of the Parliament building, Rashtrapati Bhavan, major ministry buildings, national cultural institutions and the triumphal arch- India Gate. The timeline of the project is ambitious and aims to construct the new Parliament building by July 2022, a new Secretariat by March 2024, and reshape the landscape surrounding the Central Vista by late 2020. The request for proposal (RFP) notice issued by the Ministry of Housing and Urban Affairs stated the following as the objectives of the Central Vista Redevelopment Project:

\begin{abstract}
A new Master Plan is to be drawn up for the entire Central Vista area that represents the values and aspirations of a New India - Good Governance, Efficiency, Transparency, Accountability and Equity and is rooted in the Indian Culture and social milieu... These new iconic structures shall be a legacy for 150 to 200 years at the very least. (Dutta 2019)
\end{abstract}

In light of the above-mentioned trajectory, is it possible to make sense of the radical plans of the redevelopment of Lutyens' Delhi proposed by Prime Minister Modi's government? Furthermore, I intend to understand the ideological shifts and socio-political developments that have catalysed the demolition of various ministry buildings along with the Central Vista consolidation of the ministries at one location 
which are right now spread across the city. This also extends to the North and the South Blocks of the Secretariat which are proposed to be converted into museums. Furthermore, the paper attempts to understand the process of museumification of architecture to discern the threshold between the past and the present while engaging with the process of history-making if there exists a lens to demarcate the two in the above-mentioned context. One section of this paper examines the very idea of re-conceptualisation of the Central Vista and the fate of the current buildings while the other section of the paper comparatively analyses the symbolic significance of the architectural elements of the buildings to be demolished and the buildings to be built.

\section{NEW DELHI, AN IMPERIALIST PROJECT}

On $12^{\text {th }}$ December 1911, King George V and Queen Mary announced at the Coronation Darbar that British India's capital will shift from Calcutta to Delhi. Shifting the capital has been deemed as a political and administrative strategy following the instability caused by Curzon's Bengal Partition in 1905. In essence, the shifting of the capital from Calcutta to Delhi was Lord Hardinge's (the then-Viceroy) way to dissociate from any specific provincial government and use the historicity of Delhi to consolidate the British stronghold as the supreme government (Ridley 1998). This was also an opportunity for Lord Hardinge to establish a federation of self-governing states as opposed to Lord Curzon's crusade for centralized autocracy (Moore 1985). Sengupta (2006) purports that the purpose of the capital city was never out of utility but to showcase imperial power; from the beginning when the announcement was made till the tone of the aesthetics was decided; the process was made out to be ostentatious. Though the architecture style was wildly debated in both India and England, its rudimentary appearance had been articulated long before even the architects were commissioned. Lord Hardinge wrote a memo to Lord Crewe, the Secretary of State in London, titled 'Transfer of the Capital to Delhi' and in response, Crewe writes,

The ancient walls of Delhi enshrine an imperial tradition comparable to Constantinople or that of Rome itself. (Sutton 2020: 73)

Sengupta (2006) further elaborates that reference to Rome was not in vain and the grand look associated with Rome, Nazi Berlin and Washington is called Grand Manner. Sengupta makes use of urban historian Spiro Kostof's work to explain that the Grand Manner is urban grandeur without any utility, that it was built without any pragmatic considerations. Instruments of heroic scale, luxurious building materials and visual homogeneity assert undiluted authority; the streets are built to hold pompous rituals and processions, as if the use of triumphal arches, obelisks and fountains could undermine the chaos of everyday life. Indian citizens had little or no agency to voice an opinion about the upcoming capital planning and design.

A Town Planning Committee was consolidated in 1912 to select a chief architect who would lay out the new Imperial city. Following several nominations, the Viceroy Lord Hardinge selected Sir Edwin Lutyens, an architect consulting the Hampstead Garden Suburb 
Trust in England, and husband to former Viceroy, Lord Lytton's daughter; Lutyens' friend and architect Herbert Baker was summoned for assistance (Johnson 2015). Anthony King's (1976) Marxist critique proposes that Delhi is a textbook example of a modern colonial city -the geospatial planning, as well as the structures of power involved in the decision-making process, indicate British's dismissal to harbour interests of the British Raj's Indian subjects. Lord Hardinge (1948) makes boisterous claims in his memoir that it was he who insisted on the site south of the Ridge against the better judgement of experts' opinions after site survey. Furthermore, the British convoy of planners and architects did not attempt to integrate the old city with the new one. Lutyens was dismissive of Indian architecture and remarked that Indian builders "set stones and build child wise... Before [they] erect, [they] carve every stone differently and independently, with lace patterns and terrifying shapes. On the top, [they] build over trabeated pendentives an onion" (Metcalf 1989: 228).

Johnson (2015) writes that Baker and Lutyens needed to create a city that unified architecture with Enlightenment, because, despite the British conquering India by the sword, the officials often noted that the decision of colonialism was based on reason rather than autocratic will. The geometry used in the Imperial design employs pure forms and shapes like circle, square and triangle, which were used by the architects and the planners to assert Order and Law in contrast to what they saw as chaotic indigenous planning, or lack thereof. Furthermore, Lord Hardinge, his architects, his town planners and the government bureaucracy overseeing the project believed that the new ca- pital was a gift from the British to India. According to the British, the project symbolized good government, rule of law and political reform, giving Indians greater responsibility in governance. However, Indian nationalists of the time, like Dadabhai Naoroji, would argue that the British were economically draining India and ruling by coercion. The British were losing their stronghold on India and political reforms became imperative. There was no better opportunity to assert British presence in India than building an Imperial capital to cement their position. The purpose of the city was not only to showcase British coercion, but it was also to signify that the British would reward good behaviour. The Secretariat North Block designed by Herbert Baker, flanking the Viceroy's House, is engraved with the words: "Liberty does not descend to a people... It is a blessing that must be learned before it can be enjoyed" (Vij 2014).

British concerns while deciding the site further strengthen King's argument. Irving (1981) notes that the Jamuna plain was rejected because it was considered malarial and threatening to the 'British health'. The site where the Coronation Darbar was held in north Delhi was considered too small and more importantly 'unsanitary' for its proximity to the old city. It was also important for the British that the Mughal monuments should not tower the imperial city and hence, the Raisina Hill was selected to dominate the existing landscape. According to Lutyens' initial report submitted in March 1913, the Central Vista was to be closed by a lake which would reflect the north gates of Purana Killa, built by the Mughal ruler Humayun in 1538 (Peck 2006). However, the budget of the project had to be cut down due to the outbreak of World War I and it was no 
longer possible to change the course of River Jamuna to create the lake.

The plan of the imperial Delhi is a culmination of two parts. First, the rectangular grid forming the central axis consisting of monumental government buildings and the hexagonal grid which consists of residential and other local aspects. The central axis, known as Kingsway (now Rajpath) and Queen's Way (now Janpath) helms the Viceroy House (now Rashtrapati Bhavan) on the Raisina Hill at the west end and culminates at the All India War Memorial (now India Gate) and the statue of King George V (now removed) on the east end of the axis. Various government buildings (including North Block and South Block) are placed along the central axis, easing into groves of trees and ponds on either side. The majority of local activities, whether commercial, residential or recreational, occupy a triangular base connected via hexagonal pattern links.

The Secretary of Imperial Delhi Committee, Geoffrey de Montmorency drafted the initial residential plans. The logic was to place the bureaucratic dignitaries as close to Raisina Hill as possible, while the radial concentric circles housed the rest of the government. Lutyens accepted Montmorency's formula and christened the officials into three categories: fat whites, thin whites and thin blacks (Irving 1981). While the political incorrectness may not have raised alarms in those times, the missing 'fat blacks' category is testimony that despite Lord Hardinge's attempt of creating a more inclusive federal government, Indians had no place in higher bureaucratic positions. Therefore, creating housing for 'fat blacks' must not have occurred to the master planner. Sengupta (2006) adds that while no thought was given to allocating space for senior Indian government officials, affluent Indians were allotted plots along the roads radiating from Connaught Place. These were mostly for small Indian princes. She further explains that both Indian and British businessmen were allowed in New Delhi, yet they were kept at a distance, as the purpose of the new capital was political assertion.

Cohn (1987) notes that destroying and building monuments are ways of avenging history and making way for a new narrative. The imperial capital, New Delhi, was inaugurated in 1931. In 1947, India gained Independence from the colonial British rule. New Delhi was occupied by the British for sixteen years before another discourse began on architectural expression of the political ideology representative of the post-colonial nation. New Delhi was an embarrassment to the first Prime Minister of India, Jawaharlal Nehru. In his letter to the Premier of East Punjab in 1947, he called the city 'un-Indian' (Nehru 1947). Mahatma Gandhi had proposed abandonment of the Viceroy's House (Stamp 2011).

\section{APPROPRIATING IMPERIAL NEW DELHI POST-INDEPENDENCE}

While the fate of monuments around Central Vista remained more or less unchanged, the fate of the British statues was different. After the establishment of the Parliament in 1952, the Government of India proposed a policy to remove all the statues of the British colonists (Alley 1997). While the proposals were being drafted to remove statues from all the states of India, most Parliamentarians were concerned that the landscapes in New Delhi and particularly around the Central Vista had to become 
new arenas projecting the new nationalism. However, Nehru categorised the statues of the British colonizers in three categories: historical, artistic and offensive; he proposed that, without creating international ill-will, historical and artistic symbols were to be removed gradually while the outright offensive markers were to be removed immediately (Lok Sabha Debates 1957). As a result, statues of Lord Irwin, Lord Reading and Lord Chelmsford were only removed from outside the Parliament House after Nehru's death in late 1964 (Alley 1997). Successively, the statues of Lord Willingdon from the South Block of the Secretariat and Lord Hardinge from the Rashtrapati Bhavan (President's House) were removed. Although in 1965, on $13^{\text {th }}$ August, twelve to fourteen (unidentified) people climbed on the statue of King George $\mathrm{V}$ and in a show of protest smashed the nose and the ears of the figure, it was only in 1968 that the statue was shifted to a storage facility in Old Delhi.

Lang (2010) argues that Ganesh Deolalikar (1890-1979), the first Indian to head the Central Public Works Department in Delhi (CPWD) and Shridhar Joglekar, Deolalikar's successor faced problems while developing the Mall area of New Delhi to accommodate the growing needs of the democratic government that required new institutional and administrative buildings. Despite much-debated symbolism of imperial British architects and urban planners, the two heads of CPWD adhered to the British designers' language albeit with some modifications. Much to the chagrin of the modernists'; the Supreme Court (1952), Vigyan Bhavan (1962), Udyog Bhavan (1957), Krishi Bhavan (1957) and Rail Bhavan (1962) follow the language of chhatris, chhajjas and ja- lis ${ }^{1}$ with a dome on the top. However, these buildings have been Indian-ized to fit in the Mall area without being complete replicas of the buildings designed by Lutyens and Baker. For example, Deolalikar's Supreme Court building takes cues from the dome of the Viceroy's Palace yet the chhatris supported on a square base surrounding the dome take inspiration from Fatehpur Sikri in much contrast to Lutyens' or Baker's style of designing.

The story of the architecture of Independent India is non-linear and it would be a folly to chronologically categorize development of isolated architectural styles. Mehrotra (2011) purports that in the nationalist agenda of architecture two streams emerged which were not necessarily complementary: one, the stream being folk tradition which subscribed to revivalism and the other stream adopted modernism to represent the agenda of the future. However, by 1930s, modernism had established its presence with the Nationalist Movement and architecture became an instrument to further their ideology. Nehru famously wrote to the leaders of South Asia to embrace the future: "...not go abroad in search of the past, [but] go to foreign countries in search of the present. The search is necessary, for isolation from it means backwardness and decay" (Nehru 1946, as cited by Mehrotra 2011: 30).

1 Let me explain that Chhattris are open umbrella or small dome kiosk shaped pavilions, used for decorative purposes on the top of a roof. Chhajjas overhang running along a building or an eave of a window or a door and are used to deflect direct sunlight and rain water from entering through the windows and doors. Jalis are intricately carved latticed screens added to windows to restrict porosity and allow measured ventilation and sunlight. 
Elite patrons of architecture favoured modernism as a bridge between Independent India and the rest of the world. Additionally, it was untainted with the quarrels of history or cultural restraints. Architects returning from Europe and America ${ }^{2}$ endorsed the first modernist phase of Indian architecture (1947-1975). This period is marked by influences of several international stalwarts of modernism in India including Le Corbusier, Louis Kahn, Ray and Charles Eames.

Particularly under Nehru's direction, independent New Delhi saw a momentum towards experimental modernism. Some of the landmark buildings include Habib Rahman's Ravindra Bhavan (1961) which housed Sahitya Akademi, Lalit Kala Akademi and Sangeet Natak Akademi ${ }^{3}$, Raj Rewal's Hall of Nations in the Trade Fair complex (1972), NDMC (New Delhi Municipal Corporation) building by Kuldip Singh, JK Chaudhary's IIT (Indian Institute of Technology) building and co-operative group housing scheme the Yamuna Apartments in Alaknanda commissioned by DDA (Delhi Development Authority). As I perceive it, postIndependence there were three distant 'Delhis' which were visions of different governing bodies over centuries: Shahjahanabad, Imperial New Delhi and Independent New Delhi. The political ideology came to govern the architectural expressions of the aforementioned Delhis. Mehrotra (2011) highlights that with the

2 Some of these architects were Habib Rahman (first Indian architect to be trained at MIT), Achyut Kanvinde (trained at Harvard), Gira and Gautam Sarabhai, Piloo Mody or Durga Bajpai, and later Raj Rewal, Balkrishna Doshi or Charles Correa.

3 Built to commemorate the birth centenary of Tagore. The building houses three National Academies: Plastic Arts, Literature and, Dance, Drama and Music. declaration of Emergency by Prime Minister Indira Gandhi (Jawaharlal Nehru's daughter) in 1975, Nehruvian modernism came to a halt. Furthermore, the liberalization of the economy in the 1990s under Finance Minister Manmohan Singh and Prime Minister Narasimha Rao "witnessed the rapidly disappearing role of the state in the influencing or creation of the built environment and a swiftly fading emphasis on a pan-Indian identity" (Mehrotra 2011: 33).

\section{DEMOLITION OF HALL OF NATIONS, AN EPILOGUE TO 'NEW INDIA'?}

In 2004, the Central Public Works Department (CPWD) began an unabashed discourse of tearing down the houses that were built by British architects in the Lutyens' Bungalows Zone (LBZ). These residences were built for colonial administrators and after India gained Independence, approximately $60 \%$ of these bungalows were occupied by the Government of India to house the senior officials while the remaining $40 \%$, which were in private hands, were destroyed between 1980 and 2000 (Dalrymple 2004). The debate over conservation of LBZ is controversial; while one sect believes in the sanctity of the heritage value, the other sees it as an embarrassment of a colonial past waiting to be retrofitted with the needs of the present times.

On the one hand, the place and the relevance of the icons of imperial New Delhi are being tested while on the other, the epitome of modernist architecture in New Delhi, the Hall of Nations and the Halls of Industry, were razed to the ground. In 1972, Raj Rewal's buildings in Pragati Maidan displayed Independent India's technological prowess and ingenuity at an international level; however, in 2017 these 
monuments were taken down to be replaced in the name of fanciful infrastructure.

In 2017, an agency under the Ministry of Commerce and Industry, ITPO (Indian Trade Promotions Organization) brought down five buildings: one Hall of Nations and four Halls of Industry at Pragati Maidan. Sundaram (2011) notes the Asia 72 International Trade Fair was used by the Indian National Congress (INC) to display the technological feats of Independent India, while celebrating the $25^{\text {th }}$ anniversary of the New Nation in 1972. Hence, architect Raj Rewal and engineer Mahendra Raj's buildings in Pragati Maidan not only marked the occasion by creating one of the largest spanning exhibition halls in the world but also exhibited the architectural wonder that could be born only out of the Indian context. Rewal (2017) highlights that structural engineering stalwart Buckminster Fuller was completely shocked on learning that space frames were being made from reinforced concrete rather than using the then-common practice of pre-fabricating steel space frames. Furthermore, Raj (Rewal 2017) explains that on their stringent budget, it was difficult to procure the required quantity of steel and iron, so they devised a cheaper yet ingenious construction method taking advantage of local plentiful skilled labour.

Additionally, the buildings were contextualised to the local weather conditions. For instance, the concrete flaps deflected rain and harsh sunlight and created a cool micro-climate using latticed screen (inspired by Mughal jalis) by allowing circulation of sufficient natural ventilation without using mechanical air conditioning. It is important to note that it was only in the 1980s that the Indian middle-class market saw the flooding of western produced electronic gadgets like coloured televisions, refrigerators, etcetera. Until then, most of these electronic gadgets were seen as symbols of luxury affordable only by a slim affluent class of Indians. In this sense, the replacement campus costing a whopping Rs. 2,254 crores (approximately $\$ 300$ million) (Singh 2017) with fanciful amenities, like a helipad, a hotel, an exhibition hall, a multi-level food court or a high-end shopping mall, signals a change in aspirations. It remains to be seen whether books fairs and exhibitions of discounted displays return after the expensive renovation.

The ever-changing aspirations of the capital city and inadequate conservation legislation has costed Delhi relics of its history. Dalrymple (2004) proposes only Rome and Cairo can compete with volumes of historical ruin in Delhi; however, each year more ruins fall victim to 'unscrupulous property developers and unthinking bureaucrats': "in the competition between development and heritage, it is the latter that inevitably gives way. Besides the conservation debate, one is forced to make sense of the aspiration of the architecture driven by the political ideology of the current times. Can the demolition of Hall of Nations be read as an abandonment of the ethos of Indian modernism? In a city like Delhi which has conclusive remnants of its past masters, what is the place of the Central Vista Project of 2019?

\section{CENTRAL VISTA PROJECT}

The architectural history of Central Vista is being redefined to represent the values and aspirations of a 'New India'. Prime Minister Narendra Modi states that he could neither become a part of Lutyens' world nor could he 
make the Lutyens' world a part of him, when asked about his regrets in an interview at the end of 2018; he adds he has come from a non-elite background and for him, everything is about the people of India. As Bahl explains:

There two conflicting versions of this mythical club [called Lutyens' Delhi] that Prime Minister Modi uses in his aforementioned statement -one stands for the commercial lobbyists, bureaucrats, journalists, arms dealers and politicians who were exposed during the Tehelka Sting Operation; and the other representative of 'the insufferable groups of erudite English speaking thinkers who believe in social/cultural liberalism, gender equality, small state, freer enterprise, and a dollop of welfarism. (Bahl 2019)

Since September 2019, the Central Vista Project has faced severe criticism from various factions of the civil society, including conservationists, historians, environmental activists, architects or urban planners. For instance, A. G. Krishna Menon (2019) writes that

The government appears to have perfected the art of governance by following the imperatives of 'rule by law', and avoiding the inconveniences of adhering to the necessities of the 'rule of law', to facilitate their work. (Menon 2019)

One of the foremost criticisms was the eligibility criteria for firms submitting the proposal -a minimum threshold of financial turnover and project size handled in the past restricted participation to a few firms. Eventually, six firms were eligible to submit proposals, and HCP Design, Planning and Management Pvt. Ltd., headed by Dr. Bimal Patel, a firm based out of the state of Gujarat, was selected for the design consultation.

The COVID-19 pandemic has brought forth yet another critic of the proposal. Delhi has been one of the worst affected cities in the country by the COVID-19 crisis. In such a time Sabikhi (2020) asks if it would be wiser to spend the money, Rs. 20,000 crores (approximately 2.7 billion USD), allocated for the Central Vista Redevelopment Project to mitigate the effects of the pandemic. A strong stream of criticism comes from those who question whether in the time of economic crisis building a new residence for the Prime Minister and the Vice President should be prioritised along with building a new Parliament. Consolidating the ministries along the entire Central Vista stretch would result in the loss of 'Delhi's version of New York's Central Park' (Kishore 2020). Delhi is one of the most polluted metropolis in the world, Kishore purports that the $2 \%$ core of New Delhi according to Dr. Patel's plan would triple in density adding innumerable cars creating a massive carbon footprint. Furthermore, CPWD has sought piecemeal environment clearances, the first being for the parcel of land where the new Parliament will be built. It is unclear why clearances are not being sought for the entire Central Vista Project as the environmental impact will be cumulative. An added caveat to the application is that the clearance is being filed under Category B2 of Schedule 8(a) of the Environment Impact Assessment Notification, 2006, which means that the project does not 
need public consultation and an environmental impact assessment report will not be required (Maanvi 2020).

On 20 ${ }^{\text {th }}$ March 2020, the Ministry of Housing and Urban Affairs published a gazetted notice indicating changed land use for 86.1 acres of land for the redevelopment of Central Vista in central Delhi. Let India Breathe, a collective, comprising of architects and other members of the civil society started a petition to state their objection to the Delhi Development Authority (DDA). The founder, Yash Marwah, informed of the 86.1 acres of land 80 acres were cordoned off and direct and indirect access to the general public was restricted; the space lost to general public includes spaces for recreation, public transport infrastructure, semi-public and public land use (Nath 2020). Citing Clause 5 of Chapter 10 of Master Plan for Delhi 2021 (MPD), Mr Raman added land-owning agencies and local bodies have to draft a special development plan for the conservation of heritage complexes; since the due process has not been followed, the land use pattern for Lutyens' Bungalow Zone cannot change.

Dr. Patel, architect and director of HCP, explains that for competitions of this scale, it is more important to select an architect who is capable of delivering rather than opening the competition for 'a persuasive first sketch' (Editors \& Patel 2020: 91). He adds that it is important to select an appropriate architect and not the appropriate design (Editors \& Patel 2020). Additionally, Dr. Patel explains that projects of this scale and complexity demand 'iterative design process' which essentially means the initial conception is restricted to developing 'a fuzzy concept' and surveys, studies and client requirements are developed as the project pro- gresses. Between September 2019, when the design consultants were selected, and now, Dr. Patel emphasises that several studies have been conducted to understand the traffic flow, tree inventories and infrastructure maps. On questions of public involvement in the redevelopment project and democracy, Dr. Patel points out that

$$
\begin{aligned}
& \text { Many people in the government do } \\
& \text { not believe strongly enough that } \\
& \text { it makes sense to constructively } \\
& \text { engage with the public... They are } \\
& \text { deeply suspicious of the motives } \\
& \text { of immoderate critics, advocates } \\
& \text { and activists; they have never } \\
& \text { experienced open and transpa- } \\
& \text { rent governance because they are } \\
& \text { themselves from traditional bac- } \\
& \text { kgrounds where blind faith, obe- } \\
& \text { dience and firm top-down exercise } \\
& \text { of authority are all seen as virtues; } \\
& \text { because the organizational set-up } \\
& \text { has no systems for constructive } \\
& \text { public engagement. (pp. 97) }
\end{aligned}
$$

When asked to describe the architectural vocabulary and language, Dr. Patel explains that it would be difficult for a layperson to distinguish between Lutyens' buildings and the new buildings (Friese 2020). Dr. Patel also highlights that Lutyens' Delhi has been appropriated by Indians to the extent that he thinks that many Indians imagine the space to be part of the Indian nation-state (Srivathsan 2020). However, he does add that the spire atop the new Parliament has been deployed to reference the "spires of temples and churches" because "in a vibrant democracy such as India's, the Parliament can be thought of as a sacred building" (Srivathsan 2020). 


\section{DISCUSSION}

The aesthetics of the Grand Manner were used by socialist, fascist, monarchical and authoritarian leaders to build cities symbolising the government's patronage and might; Moscow's Red Square and Nazi's re-writing of Berlin symbolize the fantasy of large-scale remodelling of cities. However, Chandravarkar (2020) argues that even a democracy can adopt traces of monumentality with a view to making citizens perceive the government as a benevolent patriarchal figure effectively, emphasising the grandeur of the head of the polity. As a result, that kind of monumentality would signify a pedestalized position of the government. In this context, I think that it would be relevant to examine whether, as a society, we ought to embrace the continuity of imperial New Delhi or explore a truly alternative spatial configuration, one in which the government and the citizens have a closer, more reciprocal relationship.

When India gained Independence, politicians and bureaucrats furiously debated to change the imperial landscape of Central Vista. Furthermore, the new buildings constructed post-Independence in the Mall area came to symbolize a union between the architectural style used by the colonizers and what they perceived as more 'Indian' elements. These elements were inspired by Buddhist, Rajputana and Mughal architecture. Chandravarkar (2020) argues that while we do not hold any obligation towards the British imperial project, we do need to reflect on the 72-year long history of India's epicentre symbolizing democratic values. Dr. Patel's statement about the current government's mistrust of their critics is alarming. Furthermore, the statement indicates that the current government and Dr. Patel do not believe in democratic participation as far as large public projects are concerned. The statement is reminiscent of the British's dismissal in involving the subjects of the Raj while building New Delhi; albeit India is no longer colonized and is the world's largest democracy.

From the various presentations made by Dr. Patel, it appears that the concerns of executing the project with ease take precedence while design aspirations are an afterthought. Specifically, in the case of the Central Vista Redevelopment Project, which is loaded with historical significance and national collective memory, 'iterative design process' fails to grasp the colossal cumulative impact. Without a well-informed thorough compendium of environmental, economic, social, cultural and historical studies (to name a few), the project appears to be on shaky ground.

Furthermore, one would wonder about the architectural representation of the muchtouted 'New India', which is being expressed through the redevelopment of Central Vista. The request for proposal (RFP) for the project emphasises on the expression of 'Indian values'; however, so far, architecturally speaking, 'Indian values' have taken on the disguise passed down from design traditions of the imperialists. References have been made to temple and church architecture; even so, it is questionable why the two places of worship have been singled out when India hosts a diversity of religions and cultures. The discourse on modernism and critical regionalism (which is the Indian adaptation of modernism) that once defined Independent India and Delhi's architecture has been completely left out as far as the Redevelopment of Central Vista is concerned. The current government's departure from the 
previous government's political ideology also seems to have resulted in the abandonment of their defining architectural legacy.

Architect and urban planner Charles Correa compared Viceroy's House to the farmer's house from Orwell's Animal Farm (Correa 2010). The animals delay burning the house after expelling the humans from the farm. Gradually, the hierarchy of power is replicated with the pigs on the top and humans are no longer needed to control the other animals. In this regard, Correa writes that "the new regime is being validated by the imagery of the old one" (Correa 2010: 63). The ninth Delhi was built to proclaim glory and magnificence to the Raj subjects by the colonizers. The masterpieces of indigenous architecture of the time were refused due acknowledgement and were portrayed as 'the work of monkeys'. If the redevelopment of Central Vista were to be the building of the tenth Delhi, one would hope it upholds the tenets of constitutional morality, reflecting the secular and democratic ideals of a constitutional republic.

Historical monuments are representational of the collective memory of any society and they are not only preserved to remember history but also to trace and define collective identity. The Central Vista Redevelopment

\section{REFERENCES}

Alley, K. 1997. Gandhiji on the Central Vista: A

Postcolonial Refiguring. Modern Asian

Studies, 31(4), pp. 967-994. Available at

www.jstor.org/stable/312851, accessed on 24 July 2020.

Bahl, R. 2019, January 22. Modi Sir, Lutyens' Delhi Made You PM - Now It Could Bring You Down. Available at https://www.thequint.
Project is controversial yet had it been better timed, it had great potential to revisit the numerous Delhis without reducing the significance of its history to the confines of museums. The indicative architectural blueprint of the Central Vista Redevelopment Project does not celebrate the rich history of the city. Moreover, the architecture of the Indian Subcontinent is reduced to spires of temples and churches. The project makes no cognizance of the problematic nature of colonial architecture. This project could have been the beginning of a nuanced dialogue between acceptance of past traumas of the city (as well as the colonial past of the Indian Subcontinent) and the aspirations for the future. While making museums out of colonial buildings may be the politically correct move, the Central Vista Redevelopment Project is a lost opportunity merely paying lip-service to selective episodes of an extremely important historical city. It is then not an overreach to say that the Central Vista Redevelopment Project furthers the agenda of polarising an already polarised nation along religious and political lines. The project emboldens a certain vision for a 'New India' envisaged by the current government which has limited space for secular and egalitarian ideas.

com/voices/opinion/raghav-bahl-onlutyens-delhi-narendra-modi-2019-loksabha-elections, accessed on 20 July 2020.

Brown, R. M. 2009. Reviving the Past: PostIndependence Architecture and Politics in India's Long 1950s. Interventions, 11(3), pp. 293-315. 
Chandavarkar, P. 2020, January 31. The undemocratic vision behind the redevelopment of Delhi's Central Vista. Available at https://caravanmagazine.in/ government/undemocratic-vision-behindredevelopment-delhi-central-vista, accessed on 10 July 2020.

Cohn, B. 1987. An Anthropologist Among the Historians and Other Essays. Oxford University Press.

Correa, C. 2010. A Place in the Shade: The New Landscape \& Other Essays. Mumbai: Penguin Random House.

Dalrymple, W. 2004, November 13. The Rubble of the Raj. Available at https://www. theguardian.com/artanddesign/2004/ nov/13/architecture.india, accessed on 29 June 2020.

Democracy, Participation and Consultation. In Conversation with Bimal Patel. 2020. Journal of Landscape Architecture, 61, pp. 84-97. Available at http://www.lajournal. in/images/61/LA-61-2020.pdf, accessed on 1 August 2020.

Dutta, A. 2019, September 13. Central Delhi Set to Get a Mega Makeover. Available at https://www.hindustantimes. com/india-news/central-delhi-setto-get-a-mega-makeover/storypmEaZVNvml4CNYtWWIC2FO.html, accessed on 10 July 2020.

Friese, K. 2020, May 24. We are turning over a fortress to the people. Available at https://www.indiatoday.in/magazine/ interview/story/20200601-we- are-turning-over-a-fortress-to-thepeople-1680812-2020-05-23, accessed on 1 July 2020.

Hardinge, C. 1948. My Indian Years, 1910-1916:

The Reminiscences of Lord Hardinge of Penhurst. London: John Murray.

Irving, R. G. 1981. Indian Summer: Lutyens, Baker, and Imperial Delhi. New Haven: Yale University Press.

Jain, A. K. 2016. The Significance of Shahjahanabad and Lutyens' Delhi. International Journal of Environmental Studies, 73:4, pp. 651-672, DOI: 10.1080/00207233.2016.1179013

Johnson, D. A. 2015. New Delhi: The Last Imperial City. Basingstoke: Palgrave Macmillan.

King, A. D. 1976. Colonial Urban Development: Culture, Social Power and Environment. London: Routledge and Kegan Paul.

Kishore, A. 2020, February 10. Government first, citizen last: Delhi Central Vista plan turns democracy on its head. Available at https:// www.newslaundry.com/2020/02/10/ government-first-citizen-last-centralvista-plan-turns-democracy-on-its-head, accessed on 15 July 2020.

Koehler, W., \& Dutta, M. C. 2010. The Raj Versus the Republic: The Legacy of Lutyens. In New Architecture and Urbanism: Development of Indian Traditions (Vol. 107, No. 111, pp. 107-111). Cambridge Scholars Publishing in association with GSE Research.

Kostof, S. 1991. The City Shaped: Urban Patterns and Meanings Through History. Bullfinch Press. 
Lang, J. 2010. A Concise History of Modern Architecture in India. New Delhi: Orient BlackSwan Private Limited.

Lok Sabha Debates, Vol. 1, 13/5/57

Maanvi. 2020, February 20. Central Vista: Why Green Clearance Sought Only for New Parliament? TheQuint. Available at https://www.thequint.com/news/india/ why-environment-clearance-soughtonly-for-central-vista-new-parliament, accessed on 29 June 2020.

Mehrotra, R. 2011. Architecture in India since 1990. Mumbai: Pictor.

Menon, A. K. 2020, May 23. Behind Modi's Plans to Redevelop the Central Vista is a Covert Political Agenda. Available at https:// thewire.in/urban/behind-modis-plans-toredevelop-the-central-vista-is-a-covertpolitical-agenda, accessed on 4 July 2020.

Metcalf, T. R. 1989. An Imperial Vision: Indian Architecture and Britain's Raj. London: Faber.

Moore, R. J. 1985. Liberalism and Indian Politics, London.

Nath, D. 2020, January 3. Architects question land use change in Central Vista revamp. The Hindu. Available at https://www. thehindu.com/news/national/architectsquestion-land-use-change-in-centralvista-revamp/article30461393.ece, accessed on 5 June 2020.

NDTV. 2019, January 1. PM Modi's New Year Interview: "2019 Will Be About Janta vs Gathbandhan." YouTube. Available at https://www.youtube.com/ watch?v=UqH8mRIxKjE, accessed on 4 July 2020.

Nehru, J. 1946. The Discovery of India. Kolkata: The Signet Press.

Nehru, J. 1947, 7 December. Letter to the Premier of East Punjab.

Peck, L. 2006. Linking Histories: The Planning of New Delhi. India International Centre Quarterly, 33(2), pp. 1-12. Available at www.jstor.org/stable/23005867, accessed on 10 July 2020.

Rewal, M. 2017. Significance of Hall of Nations - from the film „Indian Modernity“. Available at https://www.youtube.com/ watch?v=jw0mXDE6sN8\&pbjreload=101, accessed on 10 July 2020.

Ridley, J. 1998. Edwin Lutyens, New Delhi, and the Architecture of Imperialism, The Journal of Imperial and Commonwealth History, 26:2, 67-83, DOI: $10.1080 / 03086539808583025$

Sabikhi, R. 2020, April 14. In Light of the COVID-19 Pandemic, the Central Vista Project Should Be Reviewed. Available at https://thewire.in/urban/covid-19central-vista-project-new-delhi, accessed on 7 July 2020.

Sengupta, R. 2006. Enshrining an Imperial Tradition. India International Centre Quarterly, 33(2), pp. 13-26. Available at www.jstor.org/stable/23005868, accessed on 7 July 2020. 
Singh, S. 2017, May 1. Delhi watches silently as its contemporary heritage disappears. Hindustan Times.

Singh, P. 1971. The Ninth Delhi. Journal of the Royal Society of Arts, 119(5179), pp. 461-475. Available at www.jstor.org/ stable/41370745, accessed on 28 June 2020 .

Sundaram, R. 2011. Pirate modernity: Delhi's Media Urbanism. London: Routledge.

Sutton, D. 2018. Inhabited Pasts: Monuments, Authority, and People in Delhi, 19121970s. The Journal of Asian Studies, 77(4), pp. 1013-1035. doi:10.1017/ S0021911818000906

Sutton, D. 2020. Gordon Sanderson's 'Grand Programme': Architecture, Bureaucracy and Race in the Making of New Delhi, 1910-1915. South Asian Studies, 36:1, pp. 72-87, DOI: 10.1080/02666030.2020.1741246
Srivathsan, A. 2020, January 12. Whatever is built must reinforce the character Lutyens imagined: Bimal Patel. The Hindu. Available at https://www.thehindu.com/ news/cities/Delhi/whatever-is-built-mustreinforce-the-character-lutyens-imaginedbimal-patel/article30534961.ece, accessed on 24 July 2020.

Stamp, G. 2011, December. Architecture: New Delhi was inaugurated in 1931, just 16 years before the fall of the British Raj. Long dismissed as grandiose imperial pomp, it is only in recent years that Lutyens' elegant fusion of Western classicism with Eastern features has been triumphed. Apollo, 174(593).

Vij, S. 2014, October 14. Why Emperor Modi needs Nehru, Gandhi, Indira and JP. Available at https://scroll.in/article/683482/ why-emperor-modi-needs-nehru-gandhiindira-and-jp, accessed on 15 July 2020. 